\title{
The May-June 2012 Ferrara Arc earthquakes (northern Italy): structural control of the spatial evolution of the seismic sequence and of the surface pattern of coseismic fractures
}

\author{
Giusy Lavecchia ${ }^{1,{ }^{\star}}$, Rita de Nardis ${ }^{1,2}$, Daniele Cirillo ${ }^{1}$, Francesco Brozzetti ${ }^{1}$, Paolo Boncio ${ }^{1}$
${ }^{1}$ Università di Chieti-Pescara 'G. d'Annunzio', Dip. di Scienze Psicologiche, Umanistiche e della Terra, Laboratorio di Geodinamica e Sismogenesi, Chieti Scalo, Italy \\ ${ }^{2}$ Dipartimento della Protezione Civile, Roma, Italy
}

\author{
Article history \\ Received July 27, 2012; accepted August 23, 2012. \\ Subject classification: \\ Seismogenic source, Coseismic fracturing, Compressional tectonics, Ferrara arc earthquake, Po Plain.
}

\section{Introduction}

The Ferrara 2012 seismic sequence was characterized by two main compressional events, which occurred on May 20 and 29, 2012, with $M_{W} 6.1$ and $M_{W} 6.0$, respectively (quick Regional Centroid Moment Tensor [RCMT] at http:/ / autorcmt.bo.ingv.it/quicks.html). These events were followed by five events with $\mathrm{M}_{\mathrm{W}}>5.0$ (two on May 20 and three on May 29, 2012) and by hundreds of events of lower magnitudes distributed along a WNW-ESE-elongated area of ca. $500 \mathrm{~km}^{2}$ (ISIDe database at http://iside.rm.ingv.it/ iside/standard/index.jsp.). The ongoing activity of the northward-verging fold-and-thrust structures of the Ferrara-Romagna Arc (Figure 1A) and the eastward-verging Coastal Adriatic Arc (referred to as the Outer Thrust System [OTS] in Lavecchia et al. 2003) has been a debated topic in the Italian literature. Some have considered the OTS to be inactive, on the basis of seismic reflection evidence of undeformed Middle Pleistocene-Holocene deposits sealing the buried thrust fronts [Argnani et al. 1997, Bertotti et al. 1997, Di Bucci and Mazzoli 2002, Picotti et al. 2009]. Others have considered the OTS to be active and possibly seismogenic, as they recognize an associated pattern of compressional and strike slip earthquakes with P-axes mainly radial to the thrust-front direction [Lavecchia et al. 2003, Lavecchia et al. 2004, Scrocca et al. 2007, Boncio and Bracone 2009, Toscani et al. 2009, Carminati et al. 2010, Boccaletti et al. 2011, Sgroi et al. 2012]. Recent geodetic data also support the ongoing NNE motion of the Apennine compressional units above the Adriatic foreland [Serpelloni et al. 2005, Devoti et al. 2011].

The Ferrara 2012 seismic sequence activated the central, nearly E-W striking, sector of the broad Ferrara Arc. Over the past 1000 years, there have been no strong $(M \geq 5.0)$ earthquakes associated with this portion of the Arc (Figure 1B,C).
Apart from minor events $\left(\mathrm{M}_{\mathrm{W}}<4.5\right)$ in the epicentral area of the 2012 seismic sequence (Figure 1B, dotted line), the historical and instrumental catalogs report five earthquakes with $\mathrm{M}_{\mathrm{W}}$ between 4.5 and 4.7 (in 1561, 1574, 1978, 1986, 1987) [Castello et al. 2005, CPTI11 catalogue at http: / / emidius.mi. ingv.it/CPTI; ISIDe database]. Conversely, the eastern, NWSE striking segment of the Ferrara Arc has been activated by several historical earthquakes: 14 events localized around Ferrara of $4.5 \leq \mathrm{M}_{\mathrm{W}} \leq 5.5$, including the highly damaging Ferrara 1570 earthquake $\left(\mathrm{M}_{\mathrm{W}} 5.5\right.$, Io VII-VIII) and the Argenta 1624 earthquake ( $\mathrm{M}_{\mathrm{W}} 5.5$, Io VII-VIII).

The western, WSW-ENE-striking segment of the Ferrara Arc was activated at its southern end by two earthquakes of $\mathrm{M}_{\mathrm{W}} 5.5$ in 1831 and 1832, and more recently by the Reggio-Emilia 1996 earthquake $\left(M_{W}\right.$ 5.4). Since instrumental measurements have been used, a number of seismic sequences that originated at mid-to-lower crustal depths (of ca. $20-25 \mathrm{~km}$ ) have been reported, which activated the basal thrust of the Ferrara Arc (e.g., 2008, $M_{W}$ 5.5) [Bragato et al. 2012] or its antithetic splays (e.g., Faenza $2000, M_{W} 4.8$; Monghidoro 2003, $\mathrm{M}_{\mathrm{W}}$ 5.3) [Ciaccio and Chiarabba 2002, Lavecchia et al. 2003, Piccinini et al. 2006]. The focal mechanisms of all of the instrumental events possibly associated with the Ferrara Arc show prevalent reverse and reverseoblique kinematics (Figure 1C), with P-axes nearly perpendicular to the average structural trend [Boncio and Bracone 2009, Montone et al. 2012].

This study aims to provide a preliminary interpretation of the earthquake-fault association(s) of the Ferrara 2012 seismic sequence. First, on the basis of the literature data, a simplification of the complex pattern of possibly active and interconnected fold-and-thrust structures, which characterizes the Ferrara Arc, is attempted. This simplification is achieved 

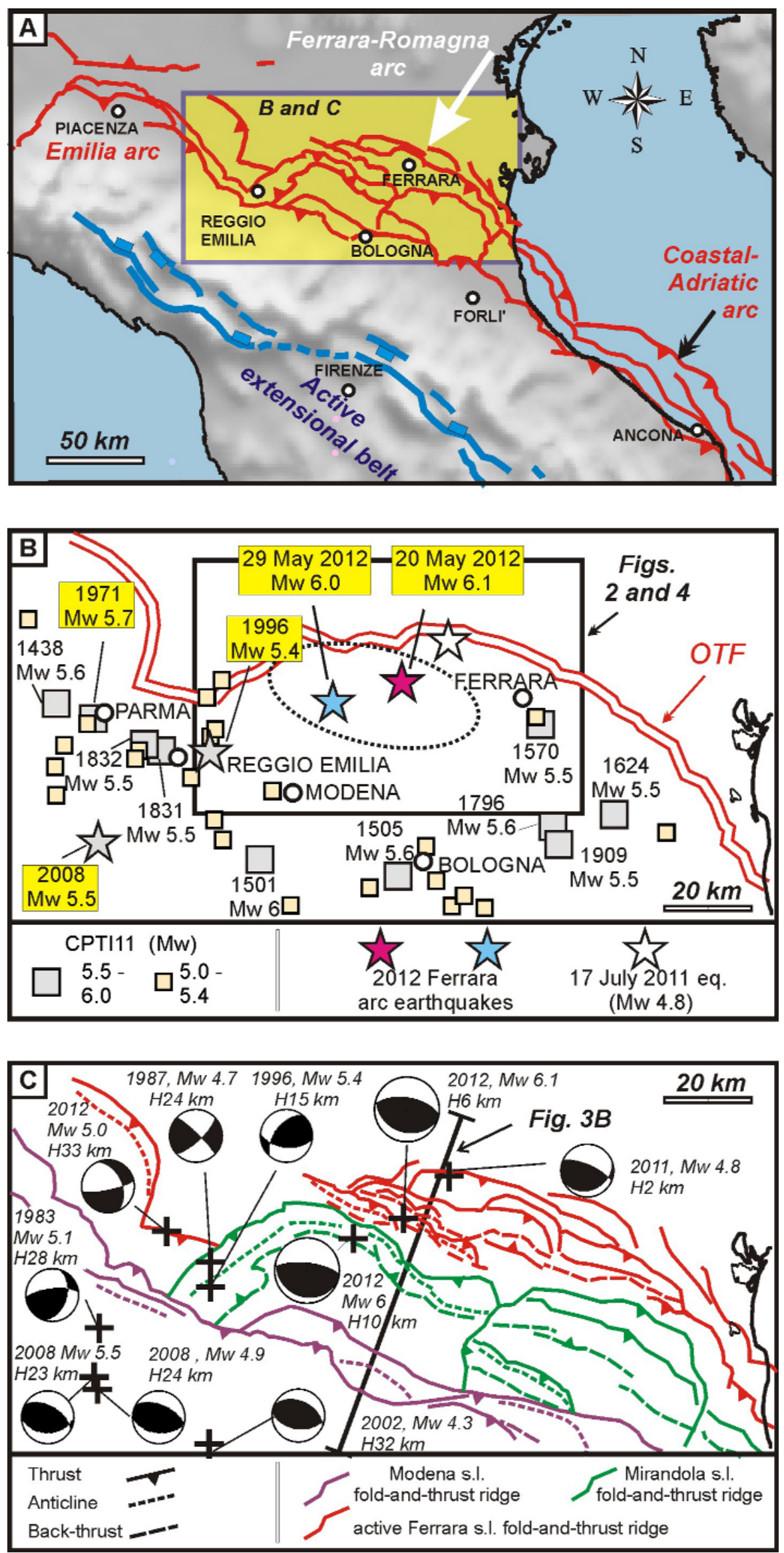

Figure 1. Seismotectonic framework of the Ferrara Arc 2012 earthquakes. (A) Schematic map of the Padan-Adriatic thrust belt of northern Italy, with the boundary of the study area (yellow rectangle). (B) Outer Thrust Front (OTF) of the Ferrara Arc, with historical and instrumental seismicity from the CPTI11 catalog and the ISIDe database. The dotted line is the areal extent of the distribution of the aftershocks for the May 19 to June 19, 2012 , period. (C) Focal mechanisms of the major events, from the RCMT catalog, available at http:/ /autorcmt.bo. ingvit/quicks.html. 
through a geometric hierarchization among the various structures involved. Secondly, the most likely seismogenic sources are preliminarily identified. Finally, the coseismic ground ruptures and the possible driving factors are discussed.

\section{Fault segments activated during the May-June 2012 seismic sequence}

\subsection{Ferrara Arc geometry and kinematics}

A comprehensive seismotectonic synthesis of the Emilia-Romagna region can be found in Boccaletti et al. [2011]. Many geological maps of the Ferrara Arc are provided by the Emilia-Romagna Geological Service (http: / / ambiente.regione.emilia-romagna.it/geologia). Also, a large number of seismic sections is available, which reveal the deep geometry of the buried thrusts [Pieri and Groppi 1981, Castellarin et al. 1985, Cassano et al. 1986]. The Ferrara Arc consists of northward-verging fold-and-thrust structures (Figure 1A), which are progressively involved in the Pliocene-Quaternary tectonic phases and are completely buried by Late Quaternary deposits. In Figure 1C, the Ferrara Arc is schematically subdivided into three major kinematic units; these are denominated from north to south as the Ferrara, Mirandola and Modena ridges. Each major ridge consists of an anticlinorium of carbonate Mesozoic terranes overthrusted above a synclinorium filled with thick piles of Plio-Pleistocene terrigenous deposits. Perpendicular to the strike, each ridge is organized into distinct and subsidiary folds and thrusts. Along the strike, the folds show periclinal closures. As a whole, the broad Ferrara Arc changes in strike from SW-NE to W-E, then to NW-SE, moving from W to E, but not all of the fold-and-thrust structures show the same rotation. For example, the Mirandola anticline axis is strongly bent (Figure 1C), and it is coaxial to its basal thrust. In other cases, the fold axes are oblique compared to their basal thrust, which implies a strike-slip component and possibly an orocline nature of the arcuate system. Given the overall prevailingly NNE-SSW-trending direction of the P-axes from focal mechanisms and borehole breakouts [Montone et al. 2012], we can assume that an almost pure dip-slip kinematics characterizes the central portion of the Ferrara Arc, a left lateral component the western portion, and a right-lateral component the eastern portion.

\subsection{The Ferrara 2012 seismic sequence}

The May 20, 2012, earthquake $\left(M_{L} 5.9, M_{W} 6.1\right)$ occurred close to the buried area of the Ferrara Arc, nearly $30 \mathrm{~km}$ WNW of the town of Ferrara and east of the Mirandola municipality (in the Modena Province) (Figure 2). This event was preceded by a $M_{L} 4.1$ event on May 19, 2012, then followed by four aftershocks with $4.8 \leq \mathrm{M}_{\mathrm{L}} \leq 5.1$ within a few hours, and then eventually by 11 events with $4.0 \leq \mathrm{M}_{\mathrm{L}} \leq 4.5$ from May 20 to 23, 2012 (ISIDe database). From May19 to 23, 2012, the seis- mic sequence covered an epicentral area extending to the WNW-ESE direction for a length of ca. $25 \mathrm{~km}$ and a width of $10 \mathrm{~km}$, from north of San Felice sul Panaro to Mirabello. During May 24 to 28, 2012, this extended further westwards for ca. $15 \mathrm{~km}$, towards Novi di Modena. The May 29, 2012, earthquake $\left(M_{L} 5.8, M_{W} 6.0\right)$ originated close to the Medolla municipality, nearly $12 \mathrm{~km}$ WSW of the May 20, 2012, event. Within a few hours, this event was followed by four aftershocks with $4.7 \leq M_{L} \leq 5.2$; on June 3, 2012, another $M_{L} 5.1$ event occurred within the same epicentral area. The aftershock sequence of the May 29, 2012, event covered an area elongated by ca. $25 \mathrm{~km}$ along the WNW-ESE direction and arranged in a left-stepping en-echelon pattern with respect to the May 20, 2012, epicentral area. The kinematics of the May 19, 2012, foreshock and the May 20 and 29, 2012, major events were almost pure thrust slip, with P-axes trending $\mathrm{N} 10^{\circ}$ and sub-perpendicular to the thrust front (Figure 2). The May 20, 2012 , fault dipped towards $\mathrm{N} 200^{\circ}$ at an average angle of $30^{\circ}$, with a NNE-SSW oriented P-axis (trend/plunge 013/15), and the May 29, 2012, fault dipped towards $\mathrm{N} 200^{\circ}$ at an average angle of $20^{\circ}$ (P-axis 010/26).

The RADARSAT images that covered the time interval from May 12 to June 5, 2012, show two distinct en-echelon, ellipse-shaped uplifts that are associated with the two events. The InSAR data from COSMO SkyMed [Salvi et al. 2012, this volume] that covered the time interval from May 27 to June 4, 2012, provide more details on the May 29, 2012, event. The epicentral area of the May 20, 2012, earthquake underwent an uplift over an area $29 \mathrm{~km}$ long (in a N120 direction) and $10 \mathrm{~km}$ to $12 \mathrm{~km}$ wide, with a maximum ground displacement of $15 \mathrm{~cm}$ between Sant'Agostino and Bondeno. The epicentral area of the May 29, 2012, earthquake underwent an uplift over an area $28 \mathrm{~km}$ long (in a $105^{\circ}$ direction) and $10 \mathrm{~km}$ to $12 \mathrm{~km}$ wide, with a maximum ground displacement of $12 \mathrm{~cm}$ near Medolla.

\subsection{Fault sources activated during the Ferrara sequence}

Figures 2 and 3 compare the surface and depth distributions of the major events (from the ISIDe database) to the geometry of the fold-and-thrust structures, and provide a preliminary seismotectonic interpretation (Figure 3, sections A, A', B). We considered previous interpretations of the line ENI, App. East-1 [Toscani et al. 2009, and references therein], as well as the geological section across the Mirandola anticline that was reconstructed by Martelli and Molinari [2008] and constrained by the Concordia 1 well (Section A). Both the map (Figures $1 \mathrm{C}$ and 2 ) and section views (Figure 3 ) indicate the presence of a small anticline, here named the Quarantoli anticline, between the Ferrara and Mirandola major ridges. We interpret the basal thrust of such a structure as an inner splay of the Ferrara thrust.

The May 20, 2012, event and its aftershocks activated the central WNW-ESE striking portion of the Ferrara ridge basal thrust, as shown in the map and section view (Figures 2, 3B). 


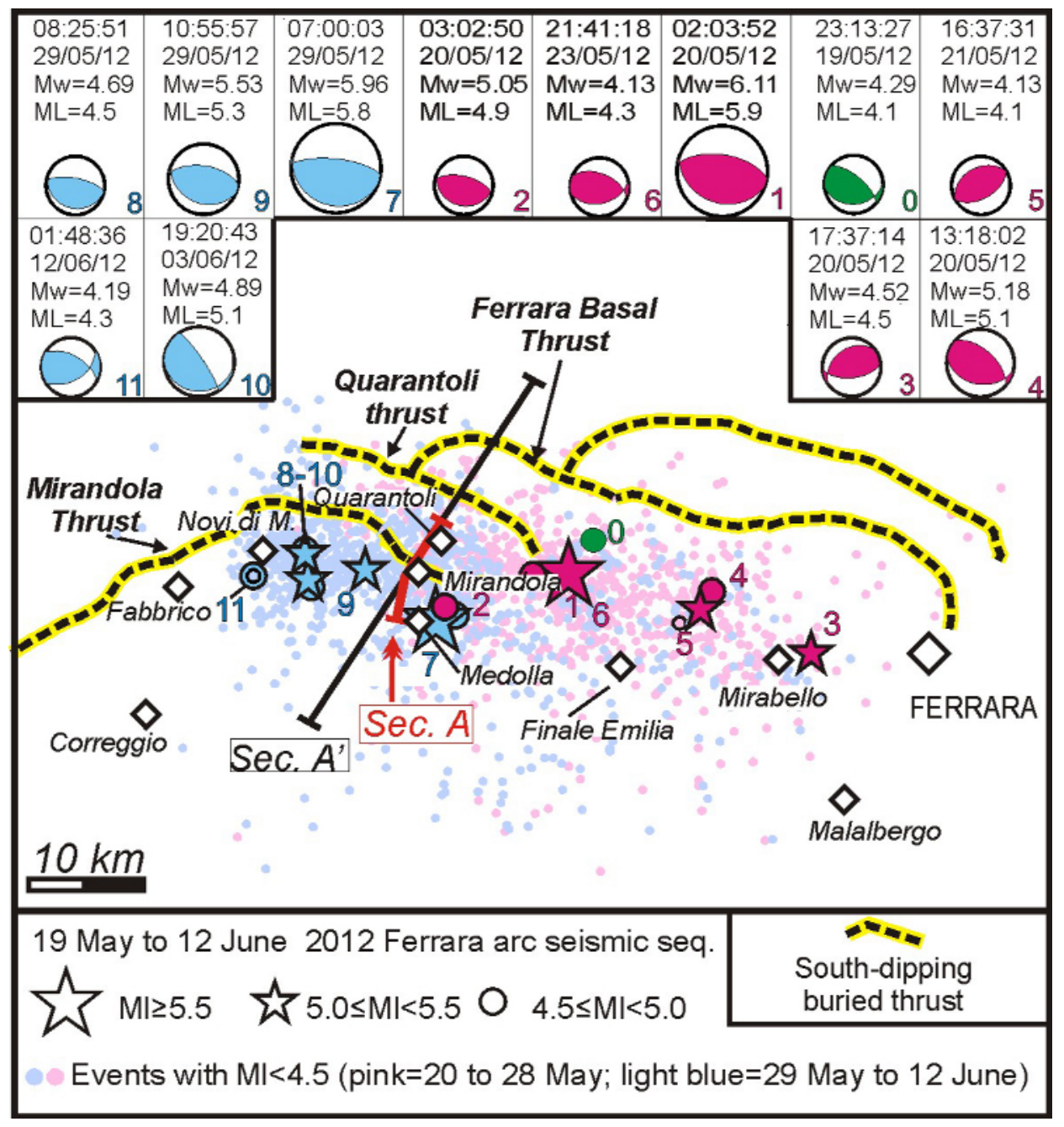

Figure 2. Seismicity and focal mechanisms related to the May 20 and 29, 2012, main events [ISIDe database and Quick RCMT catalog].

The epicentral area of the May 29, 2012, event was shifted several kilometers WNW-wards along-strike and SSW-wards along-dip. This observation might suggest the activation of the basal thrust of the Mirandola structure, which had previously been identified as a potential seismogenic source in the area [Carminati et al. 2010]. Nevertheless, on the basis of the preliminary hypocentral locations used in this study, we observe that the May 29, 2012, major events were not focused around the basal thrust of the Mirandola anticline (Figure 3A), but rather around the Quarantoli thrust (Figure 3B), which splays from the Ferrara basal thrust at a depth of nearly $10 \mathrm{~km}$, and mainly develops within the Late Paleozoic-Early Triassic sedimentary sequence. In the map view of Figure 2, the Quarantoli thrust develops along the strike further west than the Ferrara thrust, thus justifying the westwards propagation of the seismic activity. It is interesting to observe that some recent earthquakes (e.g., Figure 1C, $2008 \mathrm{M}_{\mathrm{W}} 5.5,2008 \mathrm{M}_{\mathrm{W}} 4.9$ ) that have occurred nearly $70 \mathrm{~km} \mathrm{SW-wards} \mathrm{of} \mathrm{the} \mathrm{Ferrara} 2012$ epicentral area show similar kinematics and attitude to the Ferrara 2012 events and lie just on the down-dip continuation of the Ferrara basal thrust, at depths of $20 \mathrm{~km}$ to $25 \mathrm{~km}$ [Bragato et al. 2012]. Therefore, we can hypothesize that the Ferrara Arc basal thrust is active both at upper and mid-to-lower crustal depths. This geometry is equivalent to that shown by the Adriatic basal thrust [Lavecchia et al. 2003], which is the southern continuation of the Ferrara thrust.

\section{Coseismic ground ruptures: morpho-lithologic control, tectonic origin, or both?}

Soon after the May 20 and 29, 2012, earthquakes, we carried out two geological surveys within a large area approximately coinciding with the boundary of the VI MCS mesoseismal area, to determine the occurrence of coseismic surface ruptures (Figure 4A). The large prevalence of ground fractures was associated with soil liquefaction phenomena that occurred within loose or poorly dense Quaternary alluvial sandy deposits, which prevailed along the suspended paleolevees of the abandoned river channels (e.g., the Reno, Panaro and Secchia Rivers). The most intense liquefaction processes were associated with the May 20, 2012, event and were observed between the villages of Sant'Agostino and Mirabello, along the paleo-channel of the Reno River. The liquefaction processes associated with the May 29, 2012, event were less important and mainly concentrated close to the new epicenter, with some reactivation in the area between the May 20 and 29, 2012, epicenters (e.g., Finale E., San Felice S.P.). 


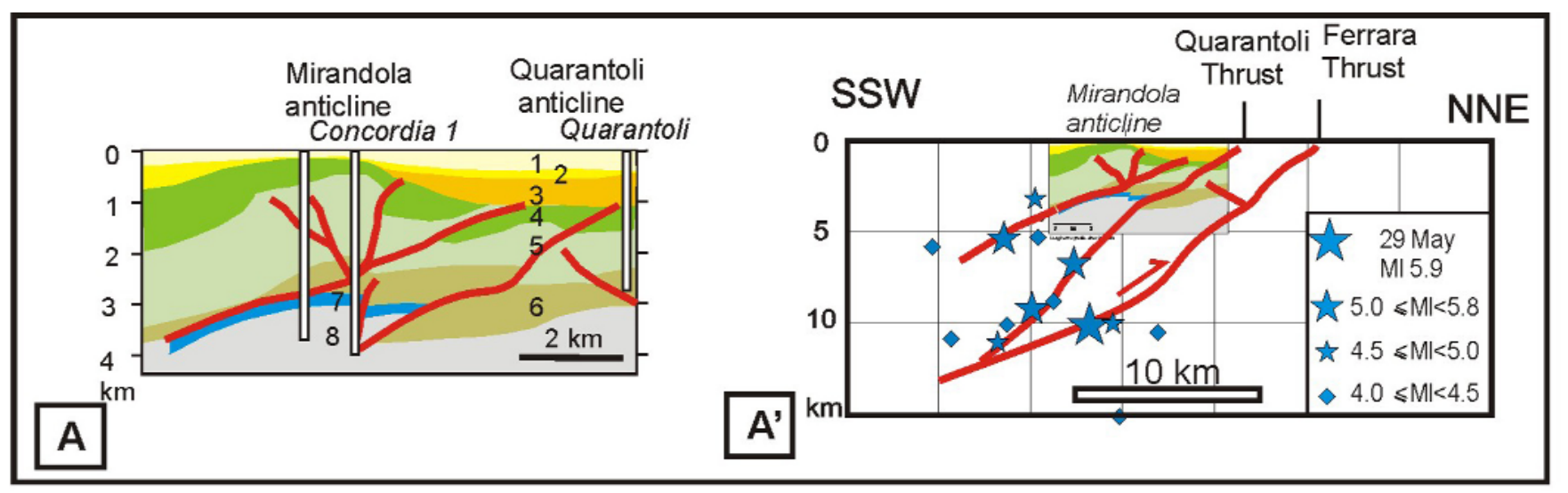

pede-Apennine Thrust System
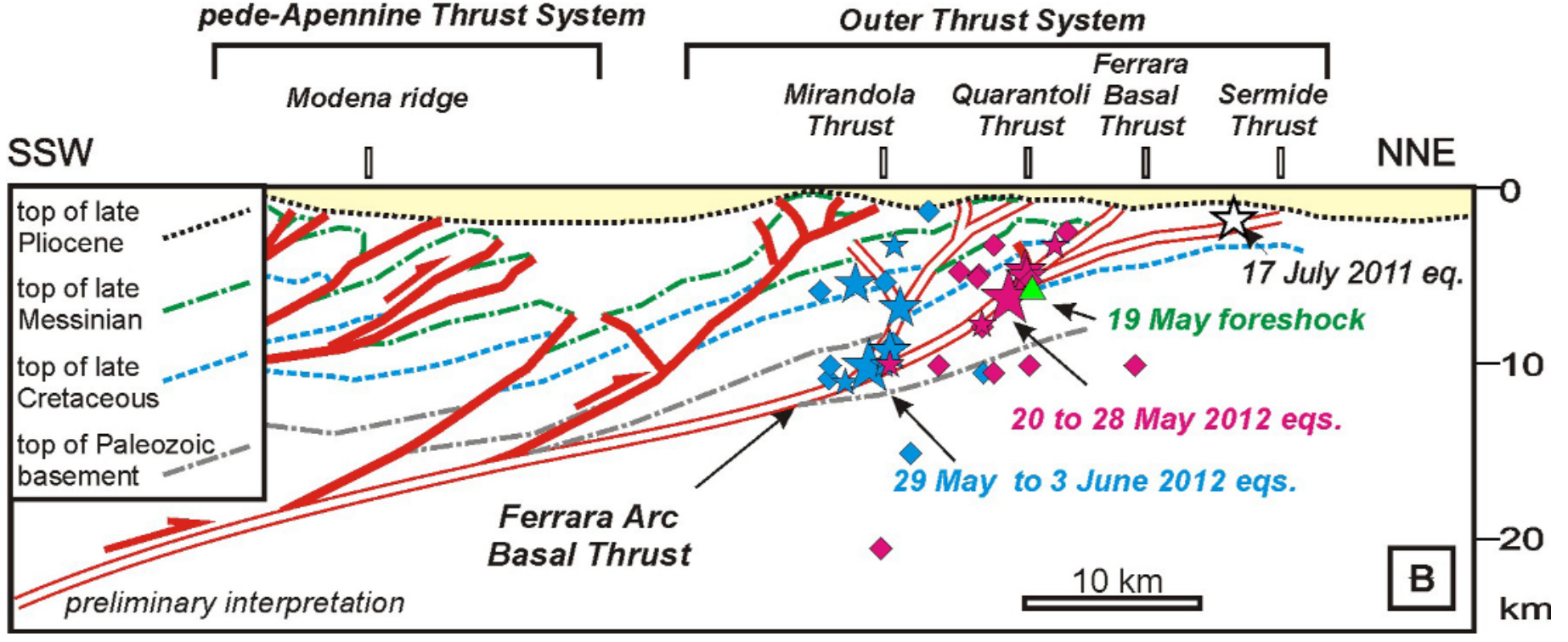

Figure 3. Interpretative sections across the Ferrara Arc (traces of sections A and A' in Figure 2, and trace of section B in Figure 1). (A) Geological section across the Mirandola anticline, from Martelli and Molinari [2008]. 1, Continental Quaternary; 2, Marine Quaternary; 3, Middle Pliocene; 4, Early Pliocene; 5, Colombacci Fm. (Late Messinian); 6, Marne di Gallare (Late Eocene-Messinian); 7, Early Cretaceous-Middle Eocene; 8, Noriglio limestone (Early Jurassic). (A') Schematic section across the Ferrara and Mirandola thrusts, compared with the May 29 to June 12, 2012 , earthquake distribution $\left(\mathrm{M}_{\mathrm{L}} \geq 4.0\right)$. (B) Regional cross-section along the line ENI, App. East-1 [modified from Toscani et al. 2009] compared with the May 29 to June 12, 2012, earthquake distribution $\left(\mathrm{M}_{\mathrm{L}} \geq 4.0\right)$.

The observed coseismic ground deformation can be subdivided into three broad classes based on their features. Class 1 comprises linear or en-echelon opened fractures, e.g., diaclasis, with openings of up to $80 \mathrm{~cm}$, with or without a vertical offset (maximum observed offset of $60 \mathrm{~cm}$ ), and often, but not systematically, accompanied by liquefaction (alignment of sand blows, sand volcanoes, ground settlements). Locally, major alignments of fractures with the vertical offset originated graben-like structures (e.g., between Sant'Agostino and Mirabello). Class 2 comprises linear ground cracks, e.g., fissures, that are generally much shorter than class 1 fractures, with very small or unappreciable opening, and generally not accompanied by liquefaction. Class 3 comprises scattered liquefaction phenomena that are not directly related to fractures (isolated or aligned sand volcanoes, well overflows). In general, the fractures cut indistinctly through farmland and human structures (e.g., roads, paved areas, buildings), and their orientations were locally conditioned by man-made structures (e.g., anthropic scarp edges) or natural features (e.g., levees). The kinematics was predominantly extensional (e.g., opening mode fractures).

To analyze the geometric patterns of the coseismic ground fractures, we integrated our field data with those collected by other investigators (Figure 4 , and references therein). The strike distribution of the compiled fracture dataset varies over a wide range of directions, from $\mathrm{N} 15^{\circ}$ to $\mathrm{N} 135^{\circ}$, with a dominant set oriented NE-SW (see Figure 4B, for rose diagrams of all of the data). The genetic interpretation of the fractures is not straightforward. It is clear that: 1) they are not surface expression of the seismogenic faults; rather, they are nearly perpendicular to them; and 2) their direction correlates well with the prevailing orientation of the present and paleoriver channels (Figure 4A). Nevertheless, the evidence suggests that the fractures - at least the longest and most continuous ones - might be of tectonic origin. The major fracture zones (FZ) are located between Sant'Agostino and Mirabello (SAMFZ, ca. $6 \mathrm{~km}$ long) and near Cavezzo (CFZ, ca. $2 \mathrm{~km} \mathrm{long,}$ N20-40) (Figure 4A). The InSAR data show that the ground 

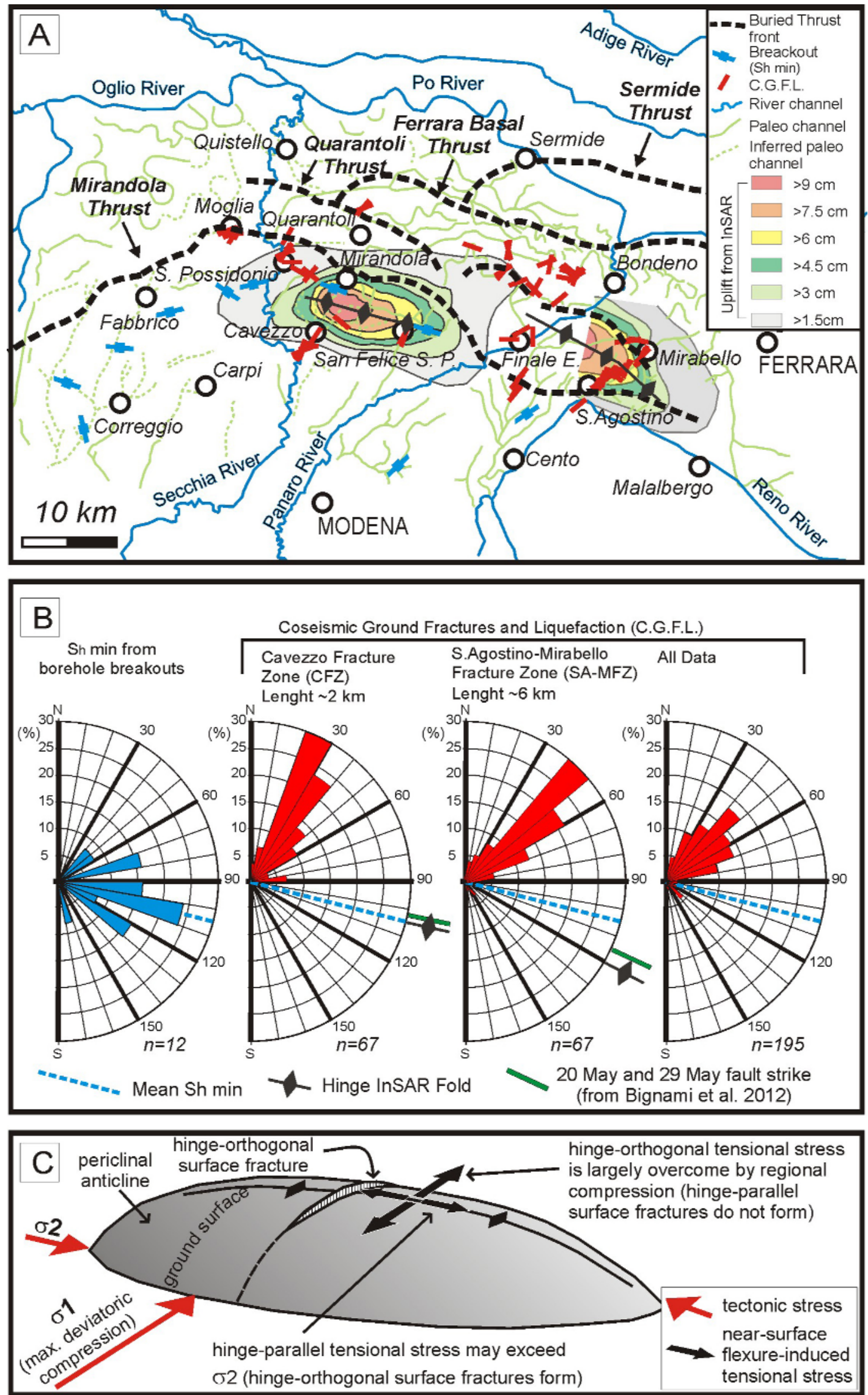

Figure 4. Map pattern (A) and rose diagrams (B) of the coseismic ground fractures and liquefaction surveyed soon after the May 20 and 29, 2012, events (our original field data are integrated with those from http:/ / ambiente.regione.emilia-romagna.it/geologia/temi/sismica/liquefazione-gruppo-di-lavoro; and from http:/ / www.eeecatalog.sinanet.apat.it/emilia/earthquake/index.php]. The river paleo-channels are from the Geological Map of the EmiliaRomagna Plain [Regione Emilia-Romagna, SELCA 1999]. (C) Possible interpretation of the major coseismic fractures in relation to the near-surface tectonic stresses caused by the earthquake. 
surface was folded coseismically, forming two hanging wall anticlines above the aftershock zones of the May 20 and 29, 2012, main shocks (Figure 4A). The domal uplift climaxes near the center of the anticlines, although it rapidly decreases when it is perpendicular and parallel to the hinge line (periclinal folds). The SA-MFZ crosses the eastern anticline close to its culmination, and the $\mathrm{CFZ}$ crosses the southern flank of the western anticline (Figure 4B). Both the SA-MFZ and the CFZ are nearly orthogonal $\left(80^{\circ}\right)$ to the cross-cut InSAR hinge line, with the western anticline rotated $15^{\circ}$ anticlockwise compared to the eastern anticline. The hinge of the western anticline is also parallel to the mean direction of the minimum horizontal stress from the borehole breakouts (Shmin; i.e., $\sigma_{2}$ ) [Montone et al. 2012]. Based on these geometric relationships, we infer that the evolution of the tectonic stress regime towards the near surface during the coseismic folding phase might have been at least one of the causes of the surface fracturing (Figure 4C). During periclinal folding, we can reasonably expect flexure-induced, near-surface tensional stresses oriented both orthogonal and parallel to the fold hinge. The tensional stress orthogonal to the hinge is also parallel to the nearly $\mathrm{N}-\mathrm{S}$ regional maximum compression $\left(\sigma_{1}\right)$ that drives the geodynamics of the area. Therefore, the component of tension is probably largely overcome by the regional compression, and is not sufficient to originate hinge-parallel tensional fractures, as observed. Conversely, tensional stress parallel to the hinge is nearly parallel to the regional $\sigma_{2}$ and might be sufficient to reduce the $\sigma_{2}$ to $\sigma_{3}$, which produces hinge-orthogonal tension fractures. In other words, the observed fractures can be interpreted as the near-surface cross-jointing of the coseismic folds.

A recent seismic survey across the Sant'Agostino-Mirabello fracture zone has pointed out that the surficial faulting/fracturing structures possibly extent to a depth of 400 meters [Borgatti et al. 2012, this volume]. Based on such observation another genetic hypothesis is here advanced. The cosesimic fractures oriented perpendicular to the fold axis may be interpreted as dilation fractures enhanced by hydraulic fracturing which may occur if the difference in magnitude of the vertical least principal stress $\left(\sigma_{3}\right)$ and of the intermediate principal stress $\left(\sigma_{2}\right)$, equals or exceed the tensile strength [Price and Cosgrove 1994].

\section{Final remarks}

The integration of subsurface geological data, historical seismicity, and the hypocentral locations of the seismic sequence of Ferrara 2012 has allowed us to develop a seismotectonic interpretation of the May 20 and 29, 2012, compressional earthquakes $\left(\mathrm{M}_{\mathrm{W}} 6.1, \mathrm{M}_{\mathrm{W}} 6.0\right)$.

Among the closely spaced and interconnected fault systems that affected the epicentral area, we have identified two potentially seismogenic sources: the Ferrara basal thrust and its Quarantoli hanging-wall splay. Considering the May 20, 2012, event, after rupturing the SSW-dipping Ferrara basal thrust at depths between $3 \mathrm{~km}$ and $7 \mathrm{~km}$ with nearly pure dip-slip kinematics, it propagated WNW-wards towards its SW-NE striking lateral ramp. For the May 29, 2012, event, the rupture jumped on an inner splay (the Quarantoli thrust) and started to again propagate WNW-wards with nearly pure dip-slip kinematics. The basal thrust of the Mirandola anticline appears to have been only subordinately involved in the sequence as, conversely, suggested by other authors [Bignami et al. 2012, this volume].

The recent compressional events that occurred at depths of $20 \mathrm{~km}$ to $25 \mathrm{~km}$ (e.g., 2008, $\mathrm{M}_{\mathrm{W}} 5.5$ and $\mathrm{M}_{\mathrm{W}}$ 4.8) and the July 2011 earthquake $\left(\mathrm{M}_{\mathrm{W}} 4.8\right.$, ca. $2 \mathrm{~km}$ in depth) can be associated to the Ferrara basal thrust, as well. These findings suggest that the system has a crustal-scale, thick-skin geometry, with the seismogenic activity possibly controlled by the rheological stratification of the crust (the seismogenic layers in sedimentary cover and in the upper part of the lower crust) [Lavecchia et al. 2003].

Finally, we suggest a possible link between the major coseismic ground fractures, which extend nearly perpendicular to the seismogenic fault structures and to the associated domal uplifts, and local switches of the principal stresses. Nevertheless, the fractures often strike parallel to river or paleo-river channels and are associated with liquefaction phenomena, which indicates that other local mechanisms also controlled the ground ruptures, such as the river morphology and facies distributions. Therefore, the fracture pattern was probably controlled by a combination of both tectonic and morpho-lithologic conditions.

\section{References}

Argnani, A., M. Bernini, G.M. Di Dio, G. Papani and S. Rogledi (1997). Stratigraphic record of crustal-scale tectonics in the Quaternary of the northern Apennines (Italy), Il Quaternario, 10, 595-602.

Bertotti, G., R. Capozzi and V. Picotti (1997). Extension controls Quaternary tectonics, geomorphology and sedimentation of the northern Apennines foothills and adjacent Po Plain (Italy), Tectonophysics, 282, 291-301.

Bignami, C., P. Burrato, V. Cannelli, M. Chini, E. Falcucci, A. Ferretti, S. Gori, C. Kyriakopoulos, D. Melini, M. Moro, F. Novali, M. Saroli, S. Stramondo, G. Valensise and P. Vannoli (2012). Coseismic deformation pattern of the Emilia 2012 seismic sequence imaged by Radarsat-1 interferometry, Annals of Geophysics, 55 (4); doi: 10.4401/ ag-6157.

Boccaletti, M., G. Corti and L. Martelli (2011). Recent and active tectonics of the external zone of the northern Apennines (Italy), Int. J. Earth Sci., 100, 1331-1348.

Boncio, P., and V. Bracone (2009). Active stress from earthquake focal mechanisms along the Padan-Adriatic side of the northern Apennines (Italy), with considerations on stress magnitudes and pore-fluid pressures, Tectono- 
physics, 476, 180-194.

Borgatti, L., A.E. Bracci, S. Cremonini and G. Martinelli (2012). Searching for the effects of the May-June 2012 Emilia seismic sequence (northern Italy): medium-depth deformation structures at the periphery of the epicentral area, Annals of Geophysics, 55 (4); doi:10.4401/ag-6131.

Bragato, P.L., M. Sugan, P. Augliera, M. Massa, A. Vuan and A. Saraò (2012). Moho reflection effects in the Po Plain (northern Italy) observed from instrumental and intensity data, B. Seismol. Soc. Am., 101, 2142-2152.

Carminati, E., D. Scrocca and C. Doglioni (2010). Copaction-induced stress variations with depth in an active anticline: northern Apennines, Italy, J. Geophys. Res., 115, 1-17.

Cassano, E., L. Anelli, R. Fichera and V. Cappelli (1986). Pianura Padana interpretazione integrata di dati geofisici e geologici, $73^{\circ}$ Congr. Soc. Geol. It., 1-28.

Castellarin, A., C. Eva, G. Giglia, G.B. Vai, E. Rabbi, G.A. Pini and G. Crestana (1985). Analisi strutturale del Fronte Appenninico Padano, Giorn. Geologia, 47, 47-75.

Castello, B., G. Selvaggi, C. Chiarabba and A. Amato (2005). CSI Catalogo della sismicità italiana 1981-2002, vers. 1.0. INGV-CNT, Roma; http: / / www.ingv.it/CSI/

Ciaccio, M.G., and C. Chiarabba (2002). Tomographic models and seismotectonics of the Reggio-Emilia region, Italy, Tectonophysics, 344, 261-276.

Devoti, R., A. Esposito, G. Pietrantonio, A.R. Pisani and F. Riguzzi (2011). Evidence of large-scale deformation patterns from GPS data in the Italian subduction boundary, Earth Planet. Sci. Lett., 311, 230-241.

Di Bucci, D., and S. Mazzoli (2002). Active tectonics of the northern Apennines and Adria geodynamics: new data and discussion, J. Geodyn., 34, 697-707.

Lavecchia, G., P. Boncio and N. Creati (2003). A lithospheric-scale seismogenic thrust in central Italy, J. Geodyn., 36, 79-94.

Lavecchia, G., P. Boncio, N. Creati and F. Brozzetti (2004). Stile strutturale e significato sismogenetico del fronte compressivo Padano-Adriatico: dati e spunti da una revisione critica del profilo CROP 03 integrata con l'analisi di dati sismologici, B. Soc. Geol. Ital., 123, 111-125.

Martelli, L., and F.C. Molinari (2008). Studio geologico finalizzato alla ricerca di potenziali serbatoi geotermici nel sottosuolo del Comune di Mirandola, Regione Emilia-Romagna, Bologna, 26 pp.

Montone, P., M.T. Mariucci and S. Pierdominici (2012). The Italian present day stress map, Geophys. J. Int., 189, 705716.

Piccinini, D., C. Chiarabba, P. Augliera and the Monghidoro Earthquake Group (M.E.G.) (2006). Compression along the northern Apennines? Evidence from the $\mathrm{M}_{\mathrm{W}} 5.3$ Monghidoro earthquake, Terra Nova, 18, 89-94.

Picotti, V., A. Ponza and F. J. Pazzaglia (2009). Topographic expression of active faults in the foothills of the northern Apennines, Tectonophysics, 474, 285-294.

Pieri, M., and G. Groppi (1981). Subsurface geological structure of the Po Plain (Italy), C.N.R., Progetto Finalizzato Geodinamica, 414, 278-286.

Price, N.J., and J.W Cosgrove (1994). Analysis of geological structures, Cambridge University Press, $502 \mathrm{pp}$.

Salvi, S., C. Tolomei, J.P. Merryman Boncori, G. Pezzo, S. Atzori, A. Antonioli, E. Trasatti, R. Giuliani, S. Zoffoli and A. Coletta (2012). Activation of the SIGRIS monitoring system for ground deformation mapping during the 2012 Emilia seismic sequence, using COSMOSkyMed InSAR data, Annals of Geophysics, 55 (4); doi:10.4401/ag-6181.

Scrocca, D., E. Carminati, C. Doglioni and D. Marcantoni (2007). Slab retreat and active shortening along the central-northern Apennines, In: O. Lacombe, J. Lavq, F. Roure and J. Verges (eds.), Thrust belts and foreland basins: from fold kinematics to hydrocarbon systems, Frontiers in Earth Sciences, Springer, 471-487.

Serpelloni, E., M. Anzidei, P. Baldi, G. Casula and A. Galvani (2005). Crustal velocity and strain-rate fields in Italy and surrounding regions: new results from the analysis of permanent and non-permanent GPS networks, Geophys. J. Int., 161, 861-880.

Sgroi, T., R. de Nardis and G. Lavecchia (2012). Crustal structure and seismotectonics of central Sicily (southern Italy): New constraints from instrumental seismicity, Geophys. J. Int. 189, 1237-1252.

Toscani, G., P. Burrato, D. Di Bucci, S. Seno and G. Valensise (2009). Plio-Quaternary tectonic evolution of the northern Apennines thrust fronts (Bologna-Ferrara section, Italy): seismotectonic implications, Ital. J. Geosci, $128,605-613$.

\footnotetext{
${ }^{\star}$ Corresponding author: Giusy Lavecchia,

Università di Chieti-Pescara 'G. d'Annunzio', Dip. di Scienze Psicologiche, Umanistiche e della Terra, Laboratorio di Geodinamica e Sismogenesi, Chieti Scalo, Italy; email: glavecchia@unich.it.

(C) 2012 by the Istituto Nazionale di Geofisica e Vulcanologia. All rights reserved.
} 